reduced root-system, narrow leaves, pale colour, \&c., the nitrogen-starved and phosphorus-starved specimens, and in those lacking all salts.

In no case, however treated were the starved or manured seedlings rendered immune. All were successfully infected by normal uredospores adapted to the normal species, though in the phosphorus.free and in the nitrogen-free seedlings, and in those deprived of all salts, there were signs of retardation of the infection, and the resulting patches and pustules of fungus spores (uredospores) were fewer and smaller.

As regards the fungus, apart from the reduced size of the mycelium, as expressed in the small pustules and retardation of development above referred to, even the reduced number of spores borne on the smallest pustules-e.g. on phosphorusstarved plants - showed no signs of morphological degeneration, or of diminished germinating capacity or virulence-i.e. capacity for infection.

The positive results; therefore, are purely quantilative. A starved plant develop: smaller pu-tules and lewer spores, simply because it can offer smaller quantities of food materials to the mycelium in its tissues; these food-materials, however, are as good in quality as they are in the case of a normal or highly manured plant. Not only so: the experiments also show that spores developed on starved seedlings can also infect seedings which have been similarly slal ved-for instance, the few spores obtained from the very minute pustules of a phosphorus-starved seedling can infect another phosphorus-starved seedling just as readily as they can a normal plant, and so on through the series.

Consequently, we must infer that predisposition and immunity on the part of the Brome, and impotence and virulence on the part of the Fungus, are alike independent of mere nutrition; and since the author has shown in previous papers ${ }^{1}$ that these properties are also independent of the anatomical structure of the host-plant, it must be concluded that the phenomena of adaptive parasitism depend on deep-seated peculiarities of the living protoplasm of the cells-possibly their capacity for forming enzymes, toxins and antitoxins, chemotactic bodies and the like, although such bodies have as yet resisted all efforts at extraction.

The full paper is illustrated with photographs and tables.

\section{THE NORTH OF ENGLAND SCIENCE CONFERENCE.}

THE first annual conference of persons in the north of England concerned in primary, secondary, technical and other forms of higher education, was held at Manchester on January 2 and 3 , and proved highly successful. The conference may be regarded as a natural outcome of similar meetings which have for some years past been held annually in London under the auspices of the London Technical Education Board. Many teachers and other educationists from the north of England have, year by year, attended the conferences in London and have become familiar with the benefits to be derived from a dis. cussion of educational methods. Believing that many teachers and others in the northern counties, anxious to reap the advan. tages springing from such meetings, were debarred from attendance by the expense of travelling, a number of prominent educationists in Lancashire and Yorkshire arranged this series of meetings in Manchester, and the phenomenally large attend. ance at all the discussions has fully justified their enterprise. More than three thousand persons accepted invitations to be present, and every meeting was characlerised by the greatest enthusiasm. It had been intended to hold all the meetings at the Manchester Municipal School of Technology, but the number of visitors to be accommodated necessitated the duplication of meetings, and a few days before the commencement of the conference arrangements were made for additional papers to be read in other places at the same time as those originally provided.

In addition to the papers and discussions, the executive com mittee provided exhibitions to illustrate methods of nature study, the teaching of experimental science, school furniture and other forms of school equipment. Demonstrations on the teaching of light and magnetism were respectively given by Mess rs. Adamson and Moore, of the Manchester Technical

1 Proc. Cambridge Philos. Soc., vol. xi. 1902, pp. 307-323; and Anrals of Botany, vol. xvi. rqo2, pp. $233^{-3} 35$. NO. 1732 , VOL. 67]
School; and, in addition, the numerous excellent educational institutions in different parts of the city were thrown open for the inspection of visitors. A conversazione, held at the School of Technology on the evening of the first day of the conference, provided a guod opportunity for teachers in different districts to become acquainted.

The method of conducting the meeting; deserves to be more widely initated in educational conferences. Immediately after the reading of a paper, the discussion of the subject was opened by one or two speakers of wide experience, who had been previnusly selected for the purpose and had prepared their remarks, with the result that the discussion was much more helpful to teachers than is usually the case on simil tr occasions. Moreover, as printed copies of the papers for discussion could be obtained immediately before the commencement of the ineetings, subsequent speakers were able to contribute something of value to the debate, and general remarks having little relation to the subject in hand were reduced to a minimum. Messrs. J. II. Reynolds and H. Llojd Snape, the honorary secretaries, are to be congratulated upon the complete success of the conference.

Half an hour before the commencement of the setious business of the conference, the visitors were welcomed by the Lord Mayor of Manchester, and his remarks were warmly endorsed by Dr. Maclure, Dean of Manchester, by Prof. Hopkinson, principal of Owens College, and by other prominent educational authorities of the district.

\section{School Curicula.}

Mr. M. E. Sadler presided at the first meeting of the conference, and in his introductory speech dealt with the aims of education. The purpose of all practical inquiry and experiment was, he said, to find the kind of training which would best equip the rising generation for their life as home-makers or wealth. makers, under the actual conditions of the modern world. The relorm of the curricula of our schools would, he thought, involve certain practical changes in the conditions under which many English teachers at present worked. Little boys ought not to be prematurely specialised in classical erudition in order to win scholarships at the public schools. In no school should any pupil fail to gain insight into the meaning of scientific method and into the operation of physical laws. In any type of curriculum, drawing and other forms of expression by means of the hand should be given a permanent place and should be worked in, as far as possible, in connection with the other subjects of study. There was a need that scientific and experimental study of erlucation should be actively carried on at the universities, with encouragement of similar investigation among teachers already at work in the schools.

Miss Burstall, head mistress of the Manchester High School for Girls, then read a paper on the curriculum in different types of schools, in which she endeavoured to find general principles by which school curricula may be tested and, if necessary, amended. Three principles were deduced ; first, the gradual adjustment of the child to the spiritual possessions of the race; second, that of training; and third, the theorem that the order of subjects in school life is conditioned by the laws of development of the child. These principles, Miss Burstall contended, lead to a broad rather than a narrow curriculum. The compulsory subjects of the curriculum for all children could be divided into three groups-English, including literature, history and geo. graphy, the humanities; science, i.e. arithmetic and nature study for young children, mathematics and science later; physical and manual training. Technical education should be reserved for the last year of school life, when the specialised study of mathematics and science required for engineering, or housewifery and the domestic arts for girls, might be taken up. The subsequent discussion was very animated, and many teachers took part in it. Mr. King, high master of the Manchester Grammar School, contended that the subjects of education did not so much matter as the method in which they were taught. Prof. Armstrong, F.R.S., deprecated a statement of Miss Burstall's that a child's reasoning powers developed late.

A paper by Mr. W. E. Hoyle, of the Manchester Museum, on the value of natural history collections for teaching purposes, was also read at Owens College during the first morning of the conference. 


\section{Coordination of Science Teaching.}

Frof. Armstrong, F.R.S., took the chair at the afternoon meeting, when Dr. Kimmins read a piper on the coordination and delimitation of science teaching in various grades of schools. He maintained that the aim of rational methods of teaching science was not the acquisition of knowledge, but ra her the training of the intelligence of the child and the development of certain mental qualities of the highest value. Useful hnowledge had been and was still the curse of science teaching. He urged that the adoption of rational methods in science teaching simplified to a remarkable degree the relation and delimitations of such teaching, and instanced the coirdination in workshop and laboratory instruction which has been so effectually secured in London schools. In the discussion which followed, Dr. Forsyth emphasised the need of a $s$ und general education for all students who intended later to enter technical colleges.

During the afternoon, Canon Rawnsley read a paper at the Central Higher Grade School on the national import of coeducation.

\section{Elementary Experimental Science.}

Prof. Smithells occupied the chair at the third meeting, when papers were read hy Mr. French, on the teaching of experi. mental physics in its early stages, and by Mr. R. L. Taylor, on the similar teaching of experimental chemistry. Mr. French described and approved the methods of teaching elementary physics advocated by the British Association committee and now very generally adopted in secondary schools. Mr. Taylor attacked, in a friendly way, the heuristic method of teaching chemistry as advocated by Prof. Armstrong, an admirable method which, he said, had become an undesirable system. A lively debate ensued, in which many speakers, following $\mathrm{Mr}$. Taylor's lead, appeared to strive to accentuate the abuses of the "research" method of teaching chemistry rather than to recognise its many advantages

Prof. Armsırong, in replying to Mr. Taylor's criticisms, said the question at issue was not merely a difference of opinion. There was a great principle at stake, and that principle wasWere they or were they not to train boys and giris at school to think for themselves, to reason for themselves, to do for themselves, to be thoughtful, observant human beings throughout the time they were at school, whenever they left school, and ever afterwards? The majority of the subjects that were taught and had been taught up to the present day had been taught in an academic, didactic and unpractical way. Britain was what it was because of the individuality of Britishers. Our modern school system was sapping our individuality. It was with the object of avoiding that loss of character that he and others were bringing practical methods into vogue.

Prof. Smithells, in a very able speech, summarised the dis. cussion, and traced many of the improvements in the teaching of science in England during the last ten years to the advocacy by Prof. Armstrong of rational methods of teaching, but at the same time pointed out there were extravagances in some of Prof. Armstrong's utterances which were, perhaps, inseparable from the work of a pioneer.

At the Central Higher (Grade School during the discussion on the heuristic method, Mr. Lomas read a paper on fitting up school laboratories.

\section{The Teaching of Nature.Study.}

The concluding meeting of the conference was presided over by Prof. Miall, F.R.S. A paper was read by Mr. H. Wager on the methods of nature-study, in which he urged that nature. study in its widest aspeces should be regarded as the study of elementary natural science, and should include, in addition to the simple facts of botany, zoology and geology, so much of elementary physics and chemistry as was concerned with the study of air and water, the condensation of moisture, frost, snow, and other simple natural phenomena. The formal study of any branch of science was not implied in it, nor was it desirable, in the earlier stages, at any rate, that they should be restricted to one branch of science only. The main objects in advocating the inclusion of nature-study in schools were (I) to urouse an interest in natural objects and phenomena, and (2) to develop to some extent the scientific method of dealing with simple problems, by the careful observation and comparison of facts and drawing inferences from them.

Prof. Weiss afterwards suggested that some portion of public parks should be made available for nature-study. He disagreed with Mr. Wager, who had deprecated the employment of dia. grams and museums, and said he could not but think that there were many objects from which lessons could usefully be learnt without having the living animal before them. They should first go to the living objects, but useful illustrations could be drawn from other countries, and where they had opportunities they should use them.

During the concluding afternoon, Mr. W. C. Fletcher, of Liverpool Institute, read a paper on the teaching of geometry, in which he generally supported the recommendations of the British Association committee.

The next conference will be held at Leeds.

A. T. S.

\section{UNIVERSITY AND EDUCATIONAL INTELLIGENCE.}

THE annual meeting of the Association of Science Masters in Public Schools will be held at the University of London on January 17.

WE learn from the Times that the Treasury has given its assent to the scheme by which Reading Corporation acquires the site and buildings of the University College at a cost of $50,000 \%$. The college, in exchange, obtains a much larger site on the London Road, whereon it is intended to erect a handsome pile of college buildings.

FROM a letter which Sir Michael Foster has addressed to Sir John Rotton, it appears that an eleclion of a new member for the University of London may not be necessary. This news will be received with great satisfaction by most of the electors, for the University has in Sir Michael Foster a representative of the high intellectual standard demanded of an academic constituency. Since expressing the wish (o) resign his seat, the circunistances which suggested that course have, most fortunately, changed, and he now desires to know whether the graduates wish him to remain their nember or not.

CANDIDATES for the Andrew Carnegie research scholarships to be awarded by the Iron and Steel Inititute must send in their applications, on a special form, before the end of February to the Secretary of the Institute, 28 Victoria Street, S.W. The object of this scheme of scholarships is not to facilitate ordinary collegiate studies, but to enable students, who have passed through a college curriculum or have been trained in industrial establishments, to conduct researches in the metallurgy of iron and steel and allied subjects, with the view of aiding its advance or its application to industry. There is no restriction as to the place of research which may be selected, whether university. technical school or works, provided it be properly equipped for the prosecution of metallurgical investigations. Last year the Andrew Carnegie gold medal was awarded to 1)r. J. $\Lambda$ Mathews, New York, and scholarships, each of the value of $100 \%$., were awarded to O. Boudouard, Paris; W. Campbell, New York; A. Campion, Coopers Hill; P. Longmuir, Manchester ; E. Schott, Berlin; and F. H. Wigham, Wakefield.

Prof. ROBERTSON, the Canadian Commissioner of Agricul. ture and Dairying, recently made a visit of investigation and observation to a portion of the State of Ohio, where re markable progress has been made in the improvement of rura schools by the plan known as that of consolidation. Instead of having a great number of small school districts, each with its own little school, these districts are united in one, and a large central school meets the needs of the whole area. The children are conveyed to and from the central school by means of vans at the expense of the rates. Prof. Roberison sums up some of the advantages afforded by the consolidation of rural schools and the free transportation of pupils. It results in the attendance of a larger number of the children in the locality, it brings about a more regular attendance of pupils of all grades of ad. vancement, it ensures teachers of higher qualifications and longer experience in rural schouls, it creates conditions for a proper classification of pupils and provides the beneficial influences of fairly large classes of pupils of about equal advancement. It makes it convenient for boys and girls in rural districts to obtain a high school education without leaving home, and leads to the erection of better school buildings and more satisfactory equipment. It makes it practicable for rural schools to teach nature-

NO. 1732 , VOL. 67] 